\title{
The engineering geology of the Tabarak Abad Dam
}

\author{
G.R. Lashkaripour $^{\mathrm{a}, *}$, M. Ghafoori ${ }^{\mathrm{b}}$ \\ ${ }^{a}$ Department of Geology, University of Sistan and Baluchestan, Zahedan, Iran \\ ${ }^{\mathrm{b}}$ Department of Geology, University of Ferdowsi, Mashhad, Iran
}

Accepted 28 January 2002

\begin{abstract}
The Tabarak Abad Dam on the river Tabarak, a branch of Atrak river, is located about $25 \mathrm{~km}$ of northeast of Quchan city in the northeast of Iran. The dam is now under construction and will be completed in 2002. The Tabarak Abad Dam has been designed as an earthfill dam with a clay core. The dam and its associated concrete structures are mainly founded on limestone and shale of the Shoorigeh formation of Upper Jurassic to Lower Cretaceous age and limestone and sandstone of the Tirgan formation of Lower Cretaceous age. These rocks are affected by high jointing and faulting especially in the surface. This paper discusses the site investigation for the dam. (C) 2002 Elsevier Science B.V. All rights reserved.
\end{abstract}

Keywords: Tabarak Abad; Iran; Dam; Site investigation

\section{Introduction}

The Tabarak Abad Dam has a crest length of 186 $\mathrm{m}$, a maximum height above river bed level of $50 \mathrm{~m}$, and a total storage capacity of 60 million $\mathrm{m}^{3}$.

The purpose of the dam construction is to provide drinking water for Quchan city about $25 \mathrm{~km}$ southeast of dam site and the villages between the dam and the same city. Furthermore, this dam will irrigate a 1150 ha area through a canal system, which is in progress. The irrigation field is situated north of Quchan city.

\section{The geology of the studied area}

Geological factors play a major role in designing and constructing a dam. Of the various natural factors

\footnotetext{
* Corresponding author.

E-mail address: lashkarg@hamoon.usb.ac.ir (G.R. Lashkaripour).
}

that influence the design of dams, none are more important than the geological ones. Not only do they control the character of formations, but they also govern the material available for construction. There exist numerous examples of projects where the conditions of the foundation were not sufficiently known and the cost of construction and treatment greatly exceeded the original budget (Ichikawa, 1999).

Information on the regional geology of the area has been given by Afshar-Harb (1984) and Mohab Ghods Engineering Company (1997). The dam and reservoir sites are located in an active seismic region of rugged mountainous terrain with steep slopes. The valley walls at the dam site are steep, with slopes of 65$70^{\circ}$ in left abutment and $45-55^{\circ}$ in the right abutment.

The main geological structures of the dam and reservoir areas are presented in Fig. 1. The significant geological structures in this figure are the Tabarak Abad Syncline Axis and Tabarak Abad Fault. The Tabarak Abad Syncline Axis with a trend of northwest to southeast is located northeast of the reservoir. 


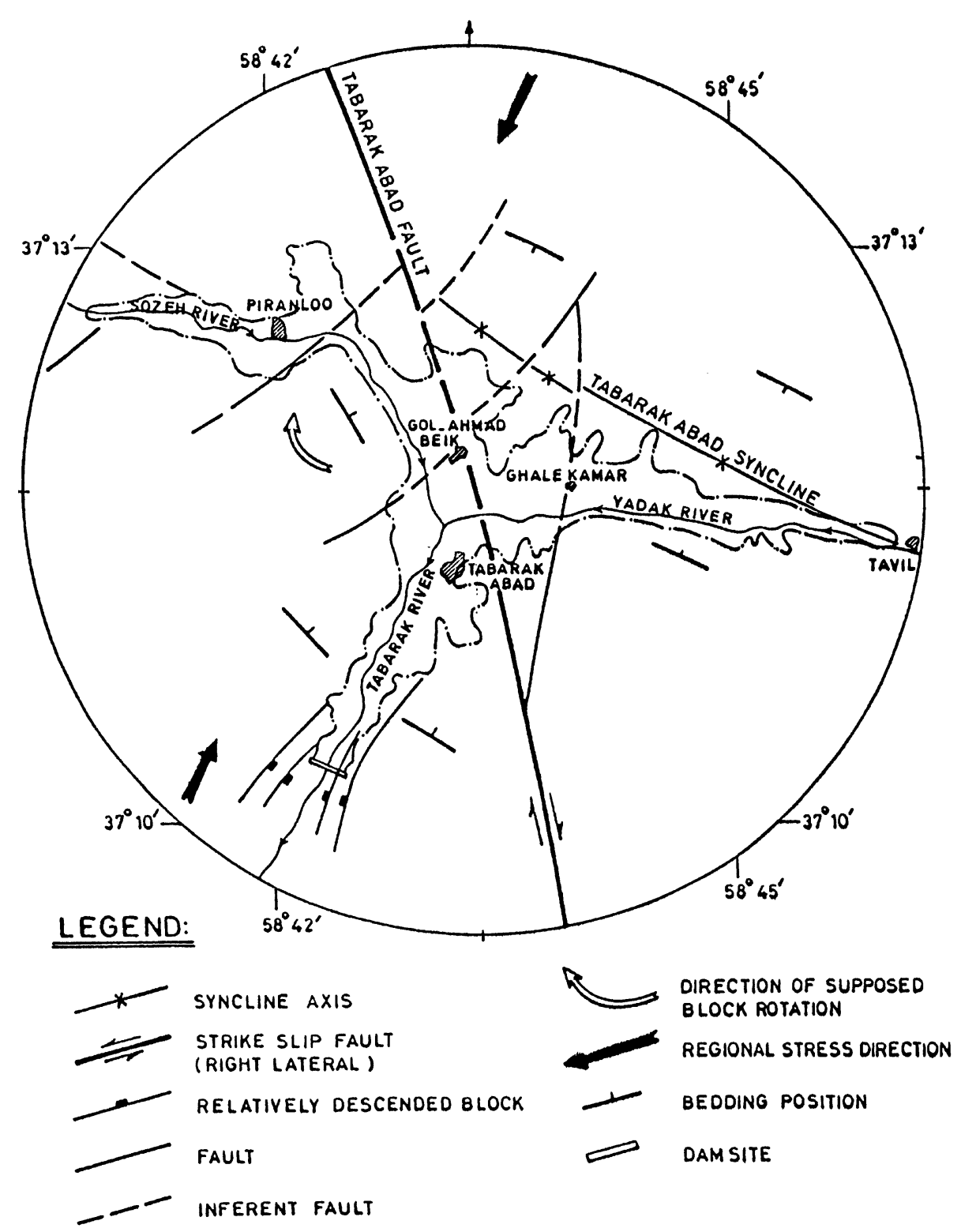

SCALE 1:50,000

Fig. 1. Tectonic sketch of the reservoir area.

The Tabarak Abad Fault is a right lateral strike-slip fault that passes about $1800 \mathrm{~m}$ east of the dam and cuts the Tabarak Abad Syncline Axis. This 25-kmlong fault is active and shows signs of displacement in the Quaternary deposits in the area. The existence of this fault and related joint systems with attendance of different tensile and shear joint systems in the site have an undesirable effect on the quality of rock mass and the permeability in the dam foundation and the reservoir.

The dam site is situated in an area underlain by Quaternary deposits and rocks units of Upper Jurassic 
and Lower Cretaceous age that consist of the following stratigraphic formations:

Sarcheshmah formation

Tirgan formation

Shoorigeh formation

\subsection{Quaternary deposits (Q)}

The Quaternary deposits are represented by alluvial and diluvial materials. The alluvium is composed of clay, silt, and rounded to subrounded course grained materials, mixed with large angular rock blocks from the Tirgan formation as the same carbonate rock on the valley wall. The maximum thickness of the Quaternary alluvium in the river valley under the dam axis is $28.6 \mathrm{~m}$ from the results of drilling.

The diluvial formation occupies areas in the foothills of the mountain slopes. This formation is represented by clay, sandy clay, and clay with gravel.

\subsection{Sarcheshmah formation}

The Sarcheshmah formation (KSC) consists of marl with limestone and sandstone layers. This formation is exposed in a small part of the right abutment and downstream. Its exposure is limited in comparison with other formations at the dam site. The Sarcheshmah formation formed in thin layers usually overlaid by alluvium at the dam site.

\subsection{Tirgan formation}

The Tirgan formation (KT) of Lower Cretaceous age overlies the shale unit of the Shoorigeh formation. This formation blankets the left and right abutments and considerable areas of the upstream of the dam with a thickness of about $70 \mathrm{~m}$. The Tirgan formation comprises of three units: KT1, KT2 and KT3.

\subsubsection{KT3 unit}

This unit is formed in the upper part of the Tirgan formation and is composed of oolitic limestone with interlayers of marly limestone and sandstone. This unit has a thickness of $45 \mathrm{~m}$ based on the results of drilling.

\subsubsection{KT2 unit}

Sandstone and sandy limestone of this unit form the middle part of the Tirgan formation. The thickness of this unit is measured $12 \mathrm{~m}$ according to the drilling results.

\subsubsection{KT1 unit}

This unit consists of oolotic limestone, limy sandstone, and thin layers of marl. The KT1 unit has a thickness of $13 \mathrm{~m}$ and overlies the shale unit of the Shoorigeh formation. This unit is exposed downstream of the dam and is overlain by the Quaternary deposits in some parts of the dam reservoir.

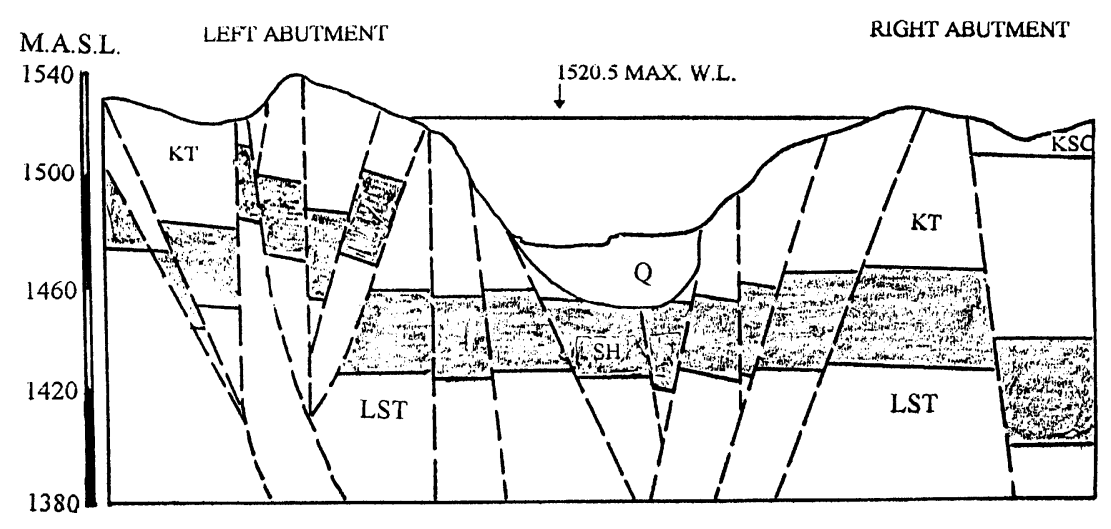

Fig. 2. The rock units and fault system across the dam axis. 
Table 1

Geotechnical parameters of the right abutment boreholes

\begin{tabular}{|c|c|c|c|c|c|c|c|c|}
\hline \multirow{2}{*}{$\begin{array}{l}\text { Borehole } \\
\text { number }\end{array}$} & \multirow{2}{*}{$\begin{array}{l}\text { Elevation } \\
\text { (m.a.s.1.) }\end{array}$} & \multirow{2}{*}{$\begin{array}{l}\text { Borehole } \\
\text { depth (m) }\end{array}$} & \multicolumn{3}{|l|}{ RQD (\%) } & \multicolumn{3}{|c|}{ Permeability (Lugeon) } \\
\hline & & & Minimum & Maximum & Average & Minimum & Maximum & Average \\
\hline B1 & 1481.0 & 25.0 & 41 & 100 & 83 & 3 & 188 & 40 \\
\hline B2 & 1483.5 & 84.0 & 0 & 100 & 89 & 0 & 299 & 40.3 \\
\hline B3 & 1481.2 & 25.0 & 66 & 100 & 91 & 5 & 382 & 198 \\
\hline B4 & 1519.7 & 82.0 & 0 & 100 & 86 & 0 & 128 & 10.7 \\
\hline $\mathrm{T} 1$ & 1492.7 & 30.0 & 0 & 95 & 76 & 1.8 & 42 & 12.5 \\
\hline $\mathrm{T} 2$ & 1514.0 & 50.0 & 0 & 100 & 85 & 0.5 & 56 & 22.5 \\
\hline $\mathrm{T} 3$ & 1485.0 & 20.0 & 0 & 100 & 68 & 0.5 & 361 & 121 \\
\hline $\mathrm{T} 4$ & 1543.8 & 20.6 & 0 & 100 & 68 & 0.7 & 45 & 16 \\
\hline $\mathrm{T} 5$ & 1476.2 & 25.0 & 45 & 100 & 83 & 62 & 101 & 75 \\
\hline T8 & 1490.4 & 25.0 & 0 & 95 & 42 & 21 & 56 & 40 \\
\hline T9 & 1523.4 & 67.0 & 0 & 100 & 87 & 0.6 & 101 & 21 \\
\hline $\mathrm{T} 14$ & 1480.3 & 25.0 & 75 & 100 & 92 & 30 & 101 & 71 \\
\hline
\end{tabular}

\subsection{Shoorigeh formation}

The Shoorigeh formation of the Upper Jurassic to Lower Cretaceous age consists of the following units:

Shale unit (SH)

Limestone unit (LST)

\subsubsection{Shale unit (SH)}

The shale unit of the upper part of the Shoorigeh formation is exposed in downstream on right abutment and in riverbed of the dam site. The thickness of the shale, according to the results of drilling, is estimated as $38 \mathrm{~m}$. Interbedded sandstone and limestone are funded in this shale unit, and they have undesirable effects on the permeability of this rock unit.

\subsubsection{Limestone unit (LST)}

The limestone composes the lower part of Shoorigeh formation of Upper Jurassic age. This unit consists of marly to sandy limestone that underlies the shale unit $(\mathrm{SH})$. It was obtained in the drilling cores and also is exposed downstream of the dam site. The thickness of this unit it not measured, but it is estimated to be about $35-40 \mathrm{~m}$. Fig. 2 shows the rock units and the fault system across the dam axis.

\section{Site investigation}

The investigation into this site took place in two stages. The dam site was geologically studied and mapped in detail. On the basis of these studies, 34 boreholes, totaling $1578 \mathrm{~m}$, were drilled. In the first

Table 2

Geotechnical parameters of the left abutment boreholes

\begin{tabular}{|c|c|c|c|c|c|c|c|c|}
\hline \multirow{2}{*}{$\begin{array}{l}\text { Borehole } \\
\text { number }\end{array}$} & \multirow{2}{*}{$\begin{array}{l}\text { Elevation } \\
\text { (m.a.s.l.) }\end{array}$} & \multirow{2}{*}{$\begin{array}{l}\text { Borehole } \\
\text { depth }(\mathrm{m})\end{array}$} & \multicolumn{3}{|l|}{ RQD (\%) } & \multicolumn{3}{|c|}{ Permeability (Lugeon) } \\
\hline & & & Minimum & Maximum & Average & Minimum & Maximum & Average \\
\hline B5 & 1487.9 & 94.4 & 0 & 100 & 87 & 0 & 292 & 94.2 \\
\hline B7 & 1530.0 & 100.0 & 0 & 100 & 74 & 0 & 236 & 81 \\
\hline B8 & 1520.0 & 50.0 & 0 & 100 & 32 & 2.7 & 156 & 97 \\
\hline B9 & 1523.0 & 114.0 & 0 & 100 & 87 & 0 & 97 & 114.9 \\
\hline $\mathrm{B} 10$ & 1536.1 & 46.0 & 0 & 100 & 71 & 0 & 280 & 379.5 \\
\hline B11 & 1488.8 & 25.3 & 0 & 100 & 85 & 26.4 & 96 & 160 \\
\hline B12 & 1480.4 & 25.0 & 0 & 100 & 60 & 23.5 & 113 & 228 \\
\hline B13 & 1529.3 & 70.0 & 20 & 100 & 93 & 0 & 21 & 24.9 \\
\hline $\mathrm{T} 10$ & 1528.1 & 60.0 & 45 & 95 & 82 & 0 & 101 & 36.4 \\
\hline T13 & 1479.2 & 40.0 & 0 & 95 & 83 & 0 & 27 & 15 \\
\hline
\end{tabular}


Table 3

Geotechnical parameters of the riverbed boreholes

\begin{tabular}{|c|c|c|c|c|c|c|c|c|c|}
\hline \multirow{2}{*}{$\begin{array}{l}\text { Borehole } \\
\text { number }\end{array}$} & \multirow{2}{*}{$\begin{array}{l}\text { Elevation } \\
\text { (m.a.s.1.) }\end{array}$} & \multirow{2}{*}{$\begin{array}{l}\text { Borehole } \\
\text { depth }(\mathrm{m})\end{array}$} & \multirow{2}{*}{$\begin{array}{l}\text { Thickness of } \\
\text { Q deposit (m) }\end{array}$} & \multicolumn{3}{|l|}{ RQD (\%) } & \multicolumn{3}{|c|}{ Permeability (Lugeon) } \\
\hline & & & & Minimum & Maximum & Average & Minimum & Maximum & Average \\
\hline $\mathrm{Ba} 1$ & 1472.1 & 40.0 & 25.7 & 35 & 100 & 90 & 0 & 9 & 1 \\
\hline $\mathrm{Ba} 2$ & 1475.4 & 43.3 & 18.6 & 43 & 100 & 87 & 0 & 3 & 0.7 \\
\hline $\mathrm{Ba} 3$ & 1475.6 & 42.0 & 25.6 & 73 & 100 & 94 & 0 & 21 & 8 \\
\hline $\mathrm{Ba} 4$ & 1472.7 & 33.0 & 23.7 & 0 & 100 & 67 & 0 & 200 & 183 \\
\hline $\mathrm{Ba} 5$ & 1473.8 & 41.0 & 26.9 & 25 & 90 & 75 & 7 & 711 & 140 \\
\hline $\mathrm{Ba} 6$ & 1473.1 & 41.7 & 24.0 & 0 & 100 & 76 & 0 & 440 & 94 \\
\hline $\mathrm{T} 15$ & 1474.0 & 33.0 & 24.7 & 95 & 100 & 97 & 3.2 & 22 & 10 \\
\hline $\mathrm{T} 12$ & 1478.1 & 40.0 & 27.0 & 22 & 100 & 73 & 45 & 101 & 73 \\
\hline
\end{tabular}

stage carried out between 1984 and 1986, 19 boreholes with total depth of $1034 \mathrm{~m}$ were drilled. The second stage was carried out between 1992 and 1993. Fifteen boreholes with total depth of $543 \mathrm{~m}$ were drilled in the second stage.

Tables 1-3 show the geotechnical parameters of the right abutment, left abutment, and riverbed boreholes, respectively. As these tables show, permeability in rock units is measured in the Lugeon scale $(0-3$ Lugeon impervious, 3-10 Lugeon low permeability, 10-30 Lugeon medium permeability, 30-60 Lugeon high permeability, and > 60 Lugeon very high permeability).

\section{Rock mass quality}

Rock mass quality is an important geological factor for design and construction of a dam project. There have been notable attempts for accurate rock mass quality classification, which not only evaluate the properties of rock masses and rock engineering geo- logical properties in the dam site, but also judge the range of utilizable rock masses around the dam and determine the reasonable excavation depth of the dam foundation.

The two well-known rock mass classification are Rock Quality Designation (RQD, Deere, 1968) and Rock Mass Rating (RMR, Bieniawski, 1973). According to the RQD values in Tables $1-3$, the quality of rocks in the right abutment is better than in the left abutment. The best quality of rock mass is found in the riverbed.

The RMR classification of the dam site rock units is shown in Table 4. As shown in this table, the rock units are classified in the range of good rock quality (class II) to poor rock quality (class IV). In addition, the quality of dam site rock masses improves with depth.

\section{Permeability}

Permeability is an important parameter in designing of a dam project. A total of 330 permeability tests

Table 4

The RMR classification of the dam site rock units

\begin{tabular}{|c|c|c|c|c|c|c|c|c|c|c|c|}
\hline \multirow[t]{3}{*}{ Parameter (rating) } & \multicolumn{11}{|c|}{ Location } \\
\hline & \multicolumn{6}{|c|}{ Right bank } & \multicolumn{5}{|c|}{ Left bank } \\
\hline & KSC & KT3 & KT2 & KT1 & $\mathrm{SH}$ & LST & KT3 & KT2 & KT1 & $\mathrm{SH}$ & LST \\
\hline RQD & 111 & 18 & 17 & 16 & 13 & 18 & 16 & 17 & 16 & 10 & 18 \\
\hline Discontinuities spacing & 7 & 8 & 9 & 8 & 8 & 9 & 8 & 8 & 8 & 7 & 9 \\
\hline Condition of discontinuities & 16 & 16 & 16 & 16 & 10 & 25 & 16 & 16 & 16 & 10 & 20 \\
\hline Groundwater & 10 & 10 & 10 & 4 & 4 & 4 & 10 & 10 & 4 & 4 & 4 \\
\hline Strength of intact rock & 5 & 11 & 9 & 8 & 4 & 8 & 9 & 8 & 4 & 8 & 4 \\
\hline Total & 49 & 63 & 61 & 52 & 39 & 64 & 61 & 60 & 52 & 35 & 59 \\
\hline Class/description & $\mathrm{III} / \mathrm{F}$ & $\mathrm{II} / \mathrm{G}$ & $\mathrm{II} / \mathrm{G}$ & $\mathrm{III} / \mathrm{F}$ & $\mathrm{IV} / \mathrm{P}$ & $\mathrm{II} / \mathrm{G}$ & $\mathrm{II} / \mathrm{G}$ & $\mathrm{III} / \mathrm{F}$ & $\mathrm{III} / \mathrm{F}$ & $\mathrm{IV} / \mathrm{P}$ & $\mathrm{II} / \mathrm{G}$ \\
\hline
\end{tabular}

II/G: good rock quality; III/F: fair rock quality; IV/P: poor rock quality. 
were carried out during the two stages of studies (54 tests in the Quaternary alluvium and 276 tests in the rock masses). The results of permeability tests on rock units are shown in Table 5. According to the results of this table, permeability in the rock units that underlie the dam foundation is high to very high. This high permeability is one of main geological engineering problems of the Tabarak Abad Dam. Therefore, improving the rock units by injection of cement is recommended for reduction of seepage flow through the foundation.

The correlation between permeability and depth for the rock units in the dam site shows a reduction in permeability with increasing depth.

\section{Strength of rock units}

The dam design process starts from estimation of ground strength, permeability, and other factors with the required level of accuracy; these should be determined through a variety of tests. A number of uniaxial compressive strength tests have been conducted to determine the strength of rock units that underlie the foundation of the dam. The results of compression tests on different rock units in dry and saturation conditions is shown in Table 6.

The results in Table 6 show that water content in shale units can significantly affect their uniaxial compressive strength in comparison with other carbonate rock units in the dam site. A number of researchers have reported the effect of water content on the uniaxial compressive strength of shale (e.g. Van Eeckhout, 1976; Steiger and Leung, 1990; Hsu and Nelson 1993; Lashkaripour, 1998, 2000). Hsu and Nelson reported a strong correlation between com-

Table 5

Results of the permeability tests

\begin{tabular}{llll}
\hline Rock unit & $\begin{array}{l}\text { Average } \\
\text { minimum } \\
\text { (Lugeon) }\end{array}$ & $\begin{array}{l}\text { Average } \\
\text { maximum } \\
\text { (Lugeon) }\end{array}$ & $\begin{array}{l}\text { Average } \\
\text { (Lugeon) }\end{array}$ \\
\hline KSC & 20 & 24 & 21 \\
KT3 & 28 & 165 & 96 \\
KT2 & 52 & 162 & 94 \\
KT1 & 21 & 110 & 59 \\
SH & 3 & 91 & 41 \\
LST & 14 & 65 & 32 \\
\hline
\end{tabular}

Table 6

Results of the compression tests on different rock units

\begin{tabular}{lll}
\hline Rock unit & $\begin{array}{l}\text { Saturated } \\
\text { condition }(\mathrm{MPa})\end{array}$ & $\begin{array}{l}\text { Dry condition } \\
(\mathrm{MPa})\end{array}$ \\
\hline KT3 & 112.4 & 115.4 \\
KT2 & $44-85$ & $98.5-110$ \\
KT1 & $39-117$ & $54-139$ \\
SH & $8-83$ & $42-133$ \\
\hline
\end{tabular}

pressive strength and water content for Cretaceous clay shales of North America. Steiger and Leung (1990) determined that, in shales, unconfined compressive strengths measured with dry samples can be 2-10 times higher than from wet samples.

\section{Conclusions}

The regional and local engineering geology have played a major role in the planning, design, construction and preference of the Tabarak Abad Dam.

The dam site and reservoir are situated in an area underlain by Upper Jurassic and Lower Cretaceous sediments, and Quaternary deposits. The dam axis intersects a fairly narrow valley of carbonate slopes and alluvial bottom.

The observed faulting and attendant fracturing and tensile and shear joints were also visible influences on the rock mass quality in the dam foundation and the reservoir area, especially in the left abutment.

The faulting and different joint systems also significantly affect the permeability of rock units in the dam foundation. Therefore, improving of the weak rock units is highly recommended.

Among the rock units in the dam site, variation in the strength of the shale unit (SH) in dry and moist or saturated conditions is much higher than for other carbonate rock units.

\section{Acknowledgements}

Field investigation described in the paper were performed by Mohab Ghods Engineering Company, for the Ministry of Energy. The writers wish to express their appreciation to the many engineers, geologists and technical staff of MGECO who contributed to the work reported in the paper. 


\section{References}

Afshar-Harb, A., 1984. Geology of Kopet-Dagh region. Geol. Surv. Iran, $281 \mathrm{pp}$.

Bieniawski, Z.T., 1973. Engineering classification of jointed rock masses. Trans. S. Afr. Inst. Civ. Eng. 15, 335-344.

Deere, D.U., 1968. Geological consideration. In: Stagg, K.G., Zienkiewicz, O.C. (Eds.), Rock Mechanics in Engineering Practice. Wiley, London.

Hsu, S.C., Nelson, P.P., 1993. Characterisation of Cretaceous clay shales in North America. In: Anagnostopoulos, A., et al. (Eds.), Proc. Int. Symp. on Geotech. Eng. of Hard Soils-Soft Rocks. Balkema, Rotterdam, pp. 139-146.

Ichikawa, K., 1999. Geological investigation of dams. Proc. of 2nd Asian Symposium on Engineering Geology and the Environment. Malaysian National Group, Bangi, Malaysia, 1-44-1-57.
Lashkaripour, G.R., 1998. The effect of water content on the mechanical behaviour of mudrocks. Proc. 8th Cong. of the International Association for Engineering Geology and the Environment, vol. 1. Balkema, Rotterdam, pp. 289-293.

Lashkaripour, G.R., 2000. Correlation between physical and mechanical properties of mudrock. J. Nepal Geol. Soc. 22, 55-60.

Mohab Ghods Engineering Company, 1997. Engineering geology report of Tabarak Abad dam site. Tabarak Abad and Barzo Project, vol. 2. Ministry of Energy, Teheran, Iran, in Persian.

Steiger, R.P., Leung, P.K., 1990. Predictions of wellbore stability in shale formations at great depth. In: Maury, V., Fourmaintraux, D. (Eds.), Rock at Great Depth. Balkema, Rotterdam, pp. 1209-1218.

Van Eeckhout, E.M., 1976. The mechanisms of strength reduction due to moisture in coal mine shales. Int. J. Rock Mech. Min. Sci. Geomech. Abstr. 13, 61-67. 